\title{
Regional signalization of chemical treatments on the base of agrophages monitoring
}

\section{Regionalna sygnalizacja terminów wykonywania zabiegów ochrony roślin na podstawie monitorowania agrofagów}

\author{
Felicyta Walczak, Andrzej Bandyk, Magdalena Jakubowska, Kamila Roik, \\ Anna Tratwal*, Beata Wielkopolan
}

\section{Summary}

The study included the annual monitoring of agrophages based on their development stages at different places in the country. A date of chemical treatment was recommended based of field observations with taking into account economical aspect. The results were distributed through the information service "Agrophages signalization" at the Institute of Plant Protection - National Research Institute web page to producers and advisors. Based on the results, it can be concluded that agrophages monitoring with a focus on disease occurrence and severity or pest incidence at a particular growth stage recommended for a control, should be performed at a specific localization (changes in microclimates between places) and every year (climate changes).

Key words: agrophages; monitoring; time of treatments

\section{Streszczenie}

Badania dotyczyły corocznego monitorowania wybranych agrofagów roślin uprawnych w zależności od ich faz rozwojowych w różnych miejscowościach na terenie kraju. Na podstawie wyników obserwacji sugerowano termin zabiegu z jednoczesnym uwzględnieniem aspektu ekonomicznego wskazującego na to, czy wykonanie zabiegu jest uzasadnione. Informacje te popularyzowano przez zamieszczanie ich w serwisie informacyjnym „Sygnalizacja Agrofagów” na stronie internetowej Instytutu Ochrony Roślin - Państwowego Instytutu Badawczego do praktycznego wykorzystania przez producentów i doradców ochrony roślin. Badania wykazały, że monitorowanie agrofagów w celu zaobserwowania pojawiania się objawów chorobowych i oceny ich stopnia nasilenia lub liczebności szkodników w określonych stadiach rozwojowych, w których należy je zwalczać, najlepiej spełnia swoją rolę jeśli jest prowadzone na konkretnej plantacji i corocznie ze względu na różny w latach przebieg warunków pogodowych.

Słowa kluczowe: agrofagi; monitorowanie; terminy zabiegów

Instytut Ochrony Roślin - Państwowy Instytut Badawczy

Zakład Metod Prognozowania Agrofagów i Ekonomiki Ochrony Roślin

Władysława Węgorka 20, 60-318 Poznań

*corresponding author: a.tratwal@iorpib.poznan.pl 


\section{Wstęp / Introduction}

Zwalczanie agrofagów roślin uprawnych jest jednym z głównych działań rolnika prowadzących do zachowania odpowiedniej wydajności i jakości plonu oraz zadawalającego zysku z produkcji rolnej. W ograniczaniu szkodliwości agrofagów ważny jest nie tylko dobór środka ochrony roślin i jego dawki, ale także wyznaczenie optymalnego terminu jego zastosowania. Obserwacje wykazały, że producenci nie zawsze potrafią wyznaczyć właściwy termin chemicznej ochrony roślin. Decydują się często na wykonanie zabiegu, gdy stwierdzają duże nasilenie objawów choroby, znaczną liczebność szkodnika lub ewidentne uszkodzenia roślin. Zastosowany wtedy zabieg jest tylko skuteczny częściowo, ale nie zawsze uzasadniony ekonomicznie i obciążający środowisko przyrodnicze.

Wykonane badania miały na celu wskazanie prawidłowego prowadzenia ochrony roślin w oparciu o sygnalizowanie konieczności wykonania zabiegów chemicznych. Określenie optymalnego terminu zabiegu wymaga monitorowania występowania agrofagów w celu stwierdzenia w jakim nasileniu występuje choroba lub w jakim stadium rozwojowym znajduje się szkodnik oraz jaka jest jego liczebność, a jeżeli został przekroczony próg ekonomicznej szkodliwości, podjęcie decyzji o wykonaniu zabiegu chemicznego.

Mając na uwadze duże zapotrzebowanie rolników i producentów na wiedzę oraz systematyczne informacje dla potrzeb prawidłowej sygnalizacji zabiegów ochrony roślin, Zakład Metod Prognozowania Agrofagów i Ekonomiki Ochrony Roślin Instytutu Ochrony Roślin - Państwowego Instytutu Badawczego (IOR - PIB) w Poznaniu (www.ior.poznan.pl) od 2005 roku prowadzi monitorowanie występowania agrofagów, którego wyniki publikowane są na stronie internetowej Instytutu w formie serwisu informacyjnego „Sygnalizacja Agrofagów” (www.stanfit. ior.agro.pl).

\section{Materiały i metody / Materials and methods}

Serwis informacyjny oparty jest na elementach systemu doradczego, takich jak:

- baza danych o agrofagach,

- wiedza o aktualnej sytuacji na plantacji (na podstawie systematycznego monitorowania agrofagów) w celu odpowiedzi na podstawowe pytania:

- w jakim terminie wykonać zabieg na konkretnej plantacji,

- czy zabieg jest uzasadniony ekonomicznie.

Obecnie serwis informacyjny „Sygnalizacja Agrofagów" obejmuje 11 punktów obserwacyjnych znajdujących się w miejscowościach: Baborówko, Słupia Wielka, Winna Góra, Kościelna Wieś (woj. wielkopolskie), Białystok (woj. podlaskie), Głuchów, Boguchwała, Nienadówka i Krzeczowice (woj. podkarpackie), Sośnicowice (woj. śląskie), Toruń (woj. kujawsko-pomorskie).

Monitorowane są wybrane agrofagi następujących gatunków roślin:
- pszenica ozima - mączniak prawdziwy zbóż i traw (Blumeria graminis), rdza brunatna pszenicy (Puccinia recondita f. sp. tritici), paskowana septorioza liści (Septoria tritici) i septorioza plew (Phaeosphaeria nodorum), mszyca czeremchowo-zbożowa (Rhopalosiphum padi), mszyca zbożowa (Sitobion avenae), pryszczarek zbożowiec (Haplodiplosis equestris), skrzypionki (Oulema spp.),

- jęczmień ozimy - mączniak prawdziwy zbóż i traw (Blumeria graminis), mszyca czeremchowo-zbożowa (Rhopalosiphum padi), mszyca zbożowa (Sitobion avenae), pryszczarek zbożowiec (Haplodiplosis equestris), skrzypionki (Oulema spp.),

- rzepak ozimy - czerń krzyżowych (Alternaria spp.), sucha zgnilizna kapustnych (Leptosphaeria spp.), zgnilizna twardzikowa (Scleritinia sclerotiorum), chowacz brukwiaczek (Ceutorhynchus napi), chowacz czterozębny (Ceutorhynchus quadridens) i słodyszek rzepakowy (Meligethes aeneus),

- burak cukrowy - chwościk buraka (Cercospora beticola), mszyca burakowa (Aphis fabae), rolnice (Noctuinae), śmietka ćwiklanka (Pegomyia hyoscyami),

- kukurydza - omacnica prosowianka (Ostrinia nubilalis),

- ziemniak - zaraza ziemniaka (Phytophthora infestans) i stonka ziemniaczana (Leptinotarsa decemlineata).

Informacje przedstawione na tej stronie są wynikiem obserwacji prowadzonych przez pracowników naukowych IOR - PIB w Poznaniu oraz Oddziału IOR - PIB w Sośnicowicach i Terenowych Stacji IOR - PIB. Ponadto obserwacje prowadzone są przez pracowników naukowych niektórych stacji doświadczalnych Centralnego Ośrodka Badania Odmian Roślin Uprawnych w Słupi Wielkiej i Instytutu Uprawy Nawożenia i Gleboznawstwa - PIB w Puławach na uprawach zlokalizowanych w wybranych miejscowościach na terenie Polski. Celem prawidłowej sygnalizacji zabiegów ochrony roślin jest monitorowanie rozwoju agrofagów oraz określenie daty, kiedy pojawi się takie nasilenie choroby lub określone stadium rozwojowe szkodnika, które wymaga konieczności wykonania zabiegu chemicznego.

Producenci, których plantacje położone były w pobliżu wymienionych punktów obserwacyjnych, w minionych latach mogli korzystać z serwisu informacyjnego „Sygnalizacja Agrofagów", w którym zamieszczano wyniki monitorowania wymienionych agrofagów w oparciu o metodyki opracowane w IOR - PIB w Poznaniu. Na ich podstawie podejmowane były decyzje o terminie wykonania zabiegu chemicznego przeciw obserwowanym w danym punkcie agrofagom. Natomiast o celowości wykonania zabiegu decydował producent po stwierdzeniu na swojej plantacji, jakie jest nasilenie choroby lub liczebność szkodnika biorąc pod uwagę próg ekonomicznej szkodliwości.

Serwis informacyjny „Sygnalizacja Agrofagów” zawiera też część edukacyjną, dzięki której producenci moga kontrolować swoje plantacje i samodzielnie podejmować decyzje dotyczące optymalnego terminu wykonania zabiegu. W tym celu dodatkowo przy każdym agrofagu (w rozdziale „O agrofagach”) znajdują się podstawowe 
informacje o jego morfologii, biologii oraz metodach prowadzenia obserwacji polowych, a także podana jest wartość progu ekonomicznej szkodliwości.

\section{Wyniki i dyskusja / Results and discussion}

Wyniki monitorowania agrofagów przedstawiono na przykładach: mączniaka prawdziwego zbóż i traw wystę- pującego na pszenicy ozimej, słodyszka rzepakowego występującego na rzepaku ozimym w latach 2012 i 2013 w różnych punktach obserwacyjnych (tab. 1-4) oraz mączniaka prawdziwego zbóż występującego na pszenicy ozimej w latach 2005-2013 i słodyszka rzepakowego występującego na rzepaku ozimym w latach 2006-2013, w miejscowości Winna Góra (tab. 5-6).

W roku 2012 objawy występowania mączniaka prawdziwego zbóż i traw na pszenicy ozimej (tab. 1)

Tabela 1. Nasilenie występowania mączniaka prawdziwego zbóż i traw na pszenicy ozimej - sezon wegetacyjny 2011/2012

Table 1. Powdery mildew incidence on winter wheat - vegetation season 2011/2012

\begin{tabular}{|c|c|c|c|c|c|c|c|c|c|c|}
\hline \multirow{3}{*}{$\begin{array}{c}\text { Data } \\
\text { obserwacji } \\
\text { Observation } \\
\text { date }\end{array}$} & \multirow{3}{*}{$\begin{array}{c}\text { Faza rozwojowa } \\
\text { Development } \\
\text { stage }\end{array}$} & \multicolumn{8}{|c|}{ Województwo - Voivodeship } & \multirow{3}{*}{$\begin{array}{c}\text { Termin } \\
\text { zabiegu } \\
\text { w } \\
\text { miejscowości } \\
\text { Time of } \\
\text { treatment } \\
\text { at place }\end{array}$} \\
\hline & & \multicolumn{4}{|c|}{ wielkopolskie } & \multirow{2}{*}{$\begin{array}{l}\text { śląskie } \\
\text { Sośnico- } \\
\text { wice }\end{array}$} & \multicolumn{2}{|c|}{ podkarpackie } & \multirow{2}{*}{$\begin{array}{l}\text { podlaskie } \\
\text { Białystok }\end{array}$} & \\
\hline & & $\begin{array}{l}\text { Babo- } \\
\text { rówko }\end{array}$ & $\begin{array}{l}\text { Winna } \\
\text { Góra }\end{array}$ & $\begin{array}{l}\text { Stupia } \\
\text { Wielka }\end{array}$ & $\begin{array}{l}\text { Kościelna } \\
\text { Wieś }\end{array}$ & & Boguchwała & $\begin{array}{l}\text { Niena- } \\
\text { dówka }\end{array}$ & & \\
\hline \multicolumn{11}{|c|}{ Procent porażonych źdźbeł pszenicy ozimej - Percentage of infected winter wheat stems } \\
\hline 16.04 & $\begin{array}{l}\text { krzewienie } \\
\text { tillering }\end{array}$ & & & & & & & 1 & & \\
\hline 17.04 & $\begin{array}{l}\text { krzewienie } \\
\text { tillering }\end{array}$ & & & & & & 1 & & & \\
\hline 24.04 & $\begin{array}{l}\text { strzelanie } \\
\text { w źdźbło } \\
\text { shooting }\end{array}$ & & & & & 10 & & & & \\
\hline 27.04 & $\begin{array}{l}\text { strzelanie } \\
\text { w źdźbło } \\
\text { shooting }\end{array}$ & 5 & & & & & & & & \\
\hline 2.05 & $\begin{array}{l}\text { strzelanie } \\
\text { w źdźbło } \\
\text { shooting }\end{array}$ & 5 & & & & & 10 & 5 & & Boguchwała \\
\hline 8.05 & $\begin{array}{l}\text { strzelanie } \\
\text { w źdźbło } \\
\text { shooting }\end{array}$ & 5 & & & & 15 & & 10 & & $\begin{array}{l}\text { Sośnicowice } \\
\text { Nienadówka }\end{array}$ \\
\hline 10.05 & $\begin{array}{l}\text { strzelanie } \\
\text { w źdźbło } \\
\text { shooting }\end{array}$ & & & & & & & & 1 & \\
\hline 14.05 & $\begin{array}{l}\text { strzelanie } \\
\text { w źdźbło } \\
\text { shooting }\end{array}$ & & 5 & 5 & 5 & & & & & \\
\hline 21.05 & $\begin{array}{c}\text { strzelanie } \\
\text { w źdźbło } \\
\text { shooting } \\
\text { grubienie pochwy } \\
\text { liściowej } \\
\text { early boot stage }\end{array}$ & & 10 & 10 & 5 & & & & & $\begin{array}{c}\text { Winna Góra } \\
\text { Słupia } \\
\text { Wielka }\end{array}$ \\
\hline 23.05 & $\begin{array}{l}\text { strzelanie } \\
\text { w źdźbło } \\
\text { shooting }\end{array}$ & 5 & & & & & & & & \\
\hline 4.05 & $\begin{array}{l}\text { kłoszenie } \\
\text { earing }\end{array}$ & & & & & & & & $\begin{array}{l}\text { po } \\
\text { terminie } \\
\text { zabiegu } \\
\text { after } \\
\text { treatment }\end{array}$ & \\
\hline 30.05 & $\begin{array}{l}\text { kłoszenie } \\
\text { earing }\end{array}$ & $\begin{array}{l}\text { po } \\
\text { terminie } \\
\text { zabiegu } \\
\text { after } \\
\text { treatment }\end{array}$ & & & & & & & & \\
\hline
\end{tabular}


Tabela 2. Nasilenie występowania mączniaka prawdziwego zbóż i traw na pszenicy ozimej - sezon wegetacyjny 2012/2013

Table 2. Powdery mildew incidence on winter wheat - vegetation season 2012/2013

\begin{tabular}{|c|c|c|c|c|c|c|c|c|c|c|c|}
\hline \multirow{3}{*}{$\begin{array}{c}\text { Data } \\
\text { obserwacji } \\
\text { Observation } \\
\text { date }\end{array}$} & \multirow{3}{*}{$\begin{array}{c}\text { Faza rozwojowa } \\
\text { Development } \\
\text { stage }\end{array}$} & \multicolumn{9}{|c|}{ Województwo - Voivodeship } & \multirow{3}{*}{$\begin{array}{c}\text { Termin } \\
\text { zabiegu } \\
\text { w } \\
\text { miejscowości } \\
\text { Time of } \\
\text { treatment } \\
\text { at place }\end{array}$} \\
\hline & & \multicolumn{4}{|c|}{ wielkopolskie } & \multirow{2}{*}{\begin{tabular}{|c|} 
śląskie \\
$\begin{array}{c}\text { Sośnico- } \\
\text { wice }\end{array}$
\end{tabular}} & \multicolumn{2}{|c|}{ podkarpackie } & \multirow{2}{*}{\begin{tabular}{|l|} 
podlaskie \\
Białystok
\end{tabular}} & \multirow{2}{*}{$\begin{array}{c}\text { kujawsko- } \\
\text { pomorskie }\end{array}$} & \\
\hline & & $\begin{array}{l}\text { Babo- } \\
\text { rówko }\end{array}$ & $\begin{array}{l}\text { Winna } \\
\text { Góra }\end{array}$ & \begin{tabular}{c|c} 
Shupia & I \\
Wielka &
\end{tabular} & $\begin{array}{c}\text { Kościelna } \\
\text { Wieś }\end{array}$ & & $\begin{array}{l}\text { Bogu- } \\
\text { chwała }\end{array}$ & $\begin{array}{l}\text { Niena- } \\
\text { dówka }\end{array}$ & & & \\
\hline \multicolumn{12}{|c|}{ Procent porażonych roślin pszenicy ozimej - Percentage of infected winter wheat stems } \\
\hline 19.04 & $\begin{array}{l}\text { krzewienie } \\
\text { tillering }\end{array}$ & & 1 & & 1 & & & & & & \\
\hline 22.04 & $\begin{array}{c}\text { krzewienie } \\
\text { tillering }\end{array}$ & & & 1 & & & & & & 1 & \\
\hline 30.04 & $\begin{array}{l}\text { krzewienie } \\
\text { tillering }\end{array}$ & & & & & & & 5 & & & \\
\hline 2.05 & $\begin{array}{l}\text { krzewienie } \\
\text { tillering }\end{array}$ & & & & & & 5 & & & & \\
\hline 9.05 & $\begin{array}{l}\text { strzelanie } \\
\text { w źdźbło } \\
\text { shooting }\end{array}$ & & & & & & 15 & & & & Boguchwała \\
\hline 10.05 & $\begin{array}{l}\text { strzelanie } \\
\text { w źdźbło } \\
\text { shooting }\end{array}$ & 5 & & & 1 & 10 & & 10 & & & $\begin{array}{l}\text { Sośnicowice } \\
\text { Nienadówka }\end{array}$ \\
\hline 15.05 & $\begin{array}{l}\text { strzelanie } \\
\text { w źdźbło } \\
\text { shooting }\end{array}$ & 10 & & & & & & & & & Baborówko \\
\hline 24.05 & $\begin{array}{c}\text { grubienie } \\
\text { pochwy liściowej } \\
\text { early boot stage }\end{array}$ & & 10 & & 5 & & & & & & Winna Góra \\
\hline 29.05 & $\begin{array}{c}\text { grubienie } \\
\text { pochwy liściowej } \\
\text { early boot stage }\end{array}$ & & & & & & & & & 10 & Toruń \\
\hline 3.06 & $\begin{array}{l}\text { kłoszenie } \\
\text { earing }\end{array}$ & & & $\begin{array}{c}5 \\
\text { po } \\
\text { terminie } \\
\text { zabiegu } \\
\text { after } \\
\text { treatment }\end{array}$ & & & & & & & \\
\hline 4.06 & $\begin{array}{l}\text { kłoszenie } \\
\text { earing }\end{array}$ & & & & & & & & $\begin{array}{c}1 \\
\text { po } \\
\text { terminie } \\
\text { zabiegu } \\
\text { after } \\
\text { treatment }\end{array}$ & & \\
\hline 7.06 & $\begin{array}{l}\text { kłoszenie } \\
\text { earing }\end{array}$ & & & & $\begin{array}{c}5 \\
\text { po } \\
\text { terminie } \\
\text { zabiegu } \\
\text { after } \\
\text { treatment }\end{array}$ & & & & & & \\
\hline
\end{tabular}

najwcześniej obserwowano w fazie krzewienia 16 kwietnia w miejscowości Nienadówka i dzień później, 17 kwietnia w miejscowości Boguchwała. W pozostałych miejscowościach pierwsze objawy zaobserwowano w fazie strzelania w źdźbło: 24 kwietnia w Sośnicowicach, 27 kwietnia w Baborówku, 7 maja w Winnej Górze, Słupi Wielkiej i Kościelnej Wsi oraz Białymstoku.
Ekonomicznie uzasadnione zabiegi przeciw mączniakowi prawdziwemu zbóż i traw wyznaczono: najwcześniej 24 kwietnia $\mathrm{w}$ fazie strzelania w źdźbło w miejscowości Boguchwała, 8 maja w Nienadówce i Sośnicowicach oraz 21 maja w Winnej Górze. Natomiast w fazie grubienia pochwy liściowej 21 maja w Słupi Wielkiej i 28 maja w Kościelnej Wsi. 
Procent porażonych źdźbeł pszenicy ozimej przez mączniaka prawdziwego zbóż i traw do fazy kłoszenia w miejscowościach Baborówko (woj. wielkopolskie) i Białystok (woj. podlaskie), nie osiągnął progu ekonomicznej szkodliwości, a w dalszych fazach rozwoju pszenicy ozimej zabiegi chemiczne nie były wskazane.

W roku 2013 objawy występowania mączniaka prawdziwego zbóż i traw na pszenicy ozimej (tab. 2) obserwowano $\mathrm{w}$ fazie krzewienia najwcześniej, bo już 19 kwietnia w miejscowościach Winna Góra i Kościelna Wieś, 22 kwietnia w miejscowościach Słupia Wielka i Toruń, 30 kwietnia w miejscowości Nienadówka oraz
2 maja w miejscowości Boguchwała. W pozostałych miejscowościach pierwsze objawy tej choroby w fazie strzelania $\mathrm{W}$ źdźbło zaobserwowano: 10 maja w Baborówku i w Sośnicowicach oraz 20 maja w Białymstoku.

Ekonomicznie uzasadnione zabiegi przeciw występowaniu mączniaka prawdziwego zbóż i traw (próg ekonomicznej szkodliwości - $10 \%$ porażonych roślin) wyznaczono: najwcześniej 9 maja w fazie strzelania w źdźbło w miejscowości Boguchwała, 10 maja w Nienadówce i Sośnicowicach oraz 15 maja w Baborówku. Natomiast w fazie grubienia pochwy liściowej: 24 maja w Winnej Górze i 29 maja w Toruniu.

Tabela 3. Początek nalotu i liczebność chrząszczy słodyszka rzepakowego na rzepaku ozimym - sezon wegetacyjny 2011/2012

Table 3. The beginning of first flight and number of blossom beetle on winter rape - vegetation season 2011/2012

\begin{tabular}{|c|c|c|c|c|c|c|}
\hline \multirow{3}{*}{$\begin{array}{c}\text { Data } \\
\text { obserwacji } \\
\text { Observation } \\
\text { date }\end{array}$} & \multirow{3}{*}{$\begin{array}{c}\text { Faza rozwojowa } \\
\text { Development stage }\end{array}$} & \multicolumn{5}{|c|}{ Województwo - Voivodeship } \\
\hline & & \multicolumn{3}{|c|}{ wielkopolskie } & \multirow{2}{*}{$\begin{array}{c}\text { śląskie } \\
\text { Sośnicowice }\end{array}$} & \multirow{2}{*}{$\begin{array}{l}\text { podlaskie } \\
\text { Białystok }\end{array}$} \\
\hline & & Winna Góra & Kościelna Wieś & Baborówko & & \\
\hline 23.03 & $\begin{array}{l}\text { wydłużenie } \\
\text { pędu głównego } \\
\text { formation } \\
\text { of side shoots }\end{array}$ & & & $\begin{array}{l}\text { początek nalotu } \\
\text { chrząszczy } \\
\text { first beetle flights }\end{array}$ & & \\
\hline 26.03 & $\begin{array}{l}\text { rozwój liści } \\
\text { leaf development }\end{array}$ & $\begin{array}{c}\text { początek nalotu } \\
\text { chrząszczy } \\
\text { first beetle flights }\end{array}$ & & & & \\
\hline 27.03 & $\begin{array}{l}\text { rozwój liści } \\
\text { leaf development }\end{array}$ & & & & $\begin{array}{c}\text { początek nalotu } \\
\text { chrząszczy } \\
\text { first beetle flights }\end{array}$ & \\
\hline 10.04 & $\begin{array}{l}\text { rozwój pąków } \\
\text { kwiatowych } \\
\text { (pąkowanie) } \\
\text { inflorescence } \\
\text { emergence }\end{array}$ & & $\begin{array}{l}\text { początek nalotu } \\
\text { chrząszczy } \\
\text { first beetle flights }\end{array}$ & & & \\
\hline 27.04 & $\begin{array}{l}\text { rozwój pąków } \\
\text { kwiatowych } \\
\text { (pąkowanie) } \\
\text { inflorescence } \\
\text { emergence }\end{array}$ & & & & & $\begin{array}{l}\text { początek nalotu } \\
\text { chrząszczy } \\
\text { first beetle flights }\end{array}$ \\
\hline \multicolumn{7}{|c|}{$\begin{array}{l}\text { Termin zabiegu }-1-2 \text { chrząszczy na roślinie przy zwartym kwiatostanie lub } 3-5 \text { przy luźnym kwiatostanie } \\
\text { Time of treatment }-1-2 \text { beetles/plant with dense inflorescence or } 3-5 \text { beetles/plant loose inflorescence }\end{array}$} \\
\hline 16.04 & $\begin{array}{l}\text { rozwój pąków } \\
\text { kwiatowych } \\
\text { (pąkowanie) } \\
\text { inflorescence } \\
\text { emergence }\end{array}$ & & & $\begin{array}{l}\text { termin zabiegu } \\
3 \text { szt./roślinę } \\
\text { time of treatment } \\
3 \text { pcs/plant }\end{array}$ & & \\
\hline 20.04 & $\begin{array}{l}\text { rozwój pąków } \\
\text { kwiatowych } \\
\text { (pąkowanie) } \\
\text { inflorescence } \\
\text { emergence }\end{array}$ & & $\begin{array}{c}\text { zalecany zabieg } \\
4 \text { szt./roślinę } \\
\text { recommended } \\
\text { treatment } \\
4 \text { pcs/plant }\end{array}$ & $\begin{array}{l}\text { wykonano zabieg } \\
\text { treatment was done }\end{array}$ & $\begin{array}{c}\text { zalecany zabieg } \\
1 \text { szt./roślinę } \\
\text { recommended } \\
\text { treatment } \\
1 \text { pcs } / \text { plant }\end{array}$ & \\
\hline 23.04 & $\begin{array}{l}\text { rozwój pąków } \\
\text { kwiatowych } \\
\text { (pąkowanie) } \\
\text { inflorescence } \\
\text { emergence }\end{array}$ & $\begin{array}{c}\text { zalecany zabieg } \\
10 \mathrm{szt} . / \text { roślinę } \\
\text { recommended } \\
\text { treatment } \\
10 \mathrm{pcs} / \text { plant }\end{array}$ & & & & \\
\hline 27.04 & $\begin{array}{l}\text { rozwój pąków } \\
\text { kwiatowych } \\
\text { (pąkowanie) } \\
\text { inflorescence } \\
\text { emergence }\end{array}$ & & & & & $\begin{array}{c}\text { zalecany zabieg } \\
1 \text { szt./roślinę } \\
\text { recommended } \\
\text { treatment } \\
1 \text { pcs/plant }\end{array}$ \\
\hline
\end{tabular}


Tabela 4. Początek nalotu i liczebność chrząszczy słodyszka rzepakowego na rzepaku ozimym - sezon wegetacyjny 2012/2013

Table 4. The beginning of first flight and number of blossom beetle on winter rape - vegetation season 2012/2013

\begin{tabular}{|c|c|c|c|c|c|c|c|}
\hline \multirow{3}{*}{$\begin{array}{c}\text { Data } \\
\text { obserwacji } \\
\text { Observation } \\
\text { date }\end{array}$} & \multirow{3}{*}{$\begin{array}{l}\text { Faza rozwojowa } \\
\text { Development stage }\end{array}$} & \multicolumn{6}{|c|}{ Województwo - Voivodeship } \\
\hline & & \multicolumn{3}{|c|}{ wielkopolskie } & \multirow{2}{*}{$\begin{array}{c}\text { śląskie } \\
\text { Sośnicowice }\end{array}$} & \multirow{2}{*}{$\begin{array}{c}\begin{array}{c}\text { kujawsko- } \\
\text { pomorskie }\end{array} \\
\text { Toruń }\end{array}$} & \multirow{2}{*}{$\begin{array}{l}\text { podlaskie } \\
\text { Białystok }\end{array}$} \\
\hline & & Winna Góra & $\begin{array}{l}\text { Kościelna } \\
\text { Wieś }\end{array}$ & Baborówko & & & \\
\hline 15.04 & $\begin{array}{l}\text { wydłużenie } \\
\text { pędu głównego } \\
\text { main stem } \\
\text { elongation }\end{array}$ & & & $\begin{array}{l}\text { początek } \\
\text { nalotu } \\
\text { chrząszczy } \\
\text { first beetle } \\
\text { flights }\end{array}$ & & & \\
\hline 16.04 & $\begin{array}{l}\text { rozwój liści } \\
\text { leaves } \\
\text { development }\end{array}$ & & & & $\begin{array}{l}\text { początek } \\
\text { nalotu } \\
\text { chrząszczy } \\
\text { first beetle } \\
\text { flights }\end{array}$ & & $\begin{array}{l}\text { początek } \\
\text { nalotu } \\
\text { chrząszczy } \\
\text { first beetle } \\
\text { flights }\end{array}$ \\
\hline \multirow[t]{2}{*}{19.04} & $\begin{array}{l}\text { rozwój liści } \\
\text { leaves } \\
\text { development }\end{array}$ & & $\begin{array}{l}\text { początek } \\
\text { nalotu } \\
\text { chrząszczy } \\
\text { first beetle } \\
\text { flights }\end{array}$ & & & & \\
\hline & & $\begin{array}{c}\text { nie } \\
\text { odnotowano } \\
\text { początku } \\
\text { nalotu } \\
\text { first beetle } \\
\text { flights were } \\
\text { not observed }\end{array}$ & & & & $\begin{array}{c}\text { nie } \\
\text { odnotowano } \\
\text { początku } \\
\text { nalotu } \\
\text { first beetle } \\
\text { flights were } \\
\text { not observed }\end{array}$ & \\
\hline
\end{tabular}

Termin zabiegu - 1-2 chrząszczy na roślinie przy zwartym kwiatostanie lub 3-5 przy luźnym kwiatostanie Time of treatment $-1-2$ beetles/plant with dense inflorescence or 3-5 beetles/plant loose inflorescence

\begin{tabular}{|c|c|c|c|c|c|c|c|}
\hline 24.04 & $\begin{array}{l}\text { rozwój pąków } \\
\text { kwiatowych } \\
\text { (pąkowanie) } \\
\text { inflorescence } \\
\text { emergence }\end{array}$ & & & & $\begin{array}{c}\text { zalecany zabieg } \\
3 \text { szt./roślinę } \\
\text { recommended } \\
\text { treatment } \\
3 \text { pcs } / \text { plant }\end{array}$ & & \\
\hline 26.04 & $\begin{array}{l}\text { rozwój pąków } \\
\text { kwiatowych } \\
\text { (pąkowanie) } \\
\text { iInflorescence } \\
\text { emergence }\end{array}$ & & & $\begin{array}{l}\text { zalecany zabieg } \\
2 \text { szt./roślinę } \\
\text { recommended } \\
\text { treatment } \\
2 \mathrm{pcs} / \text { plant }\end{array}$ & & & \\
\hline 29.04 & $\begin{array}{l}\text { rozwój pąków } \\
\text { kwiatowych } \\
\text { (pąkowanie) } \\
\text { inflorescence } \\
\text { emergence }\end{array}$ & $\begin{array}{c}\text { zalecany zabieg } \\
3 \text { szt./roślinę } \\
\text { recommended } \\
\text { treatment } \\
3 \text { pcs } / \text { plant }\end{array}$ & & & & & \\
\hline 4.05 & $\begin{array}{l}\text { kwitnienie } \\
\text { flowering }\end{array}$ & & $\begin{array}{c}\text { zalecany zabieg } \\
7 \text { szt./rośline } \\
\text { recommended } \\
\text { treatment } \\
7 \mathrm{pcs} / \text { plant }\end{array}$ & & & & \\
\hline 6.05 & $\begin{array}{l}\text { rozwój pąków } \\
\text { kwiatowych } \\
\text { (pąkowanie) } \\
\text { inflorescence } \\
\text { emergence }\end{array}$ & & & & & & $\begin{array}{c}\text { zalecany } \\
\text { zabieg } \\
2 \text { szt./roślinę } \\
\text { recommended } \\
\text { treatment } \\
2 \text { pcs/plant }\end{array}$ \\
\hline 8.05 & $\begin{array}{l}\text { rozwój pąków } \\
\text { kwiatowych } \\
\text { (pąkowanie) } \\
\text { inflorescence } \\
\text { emergence }\end{array}$ & & & & & $\begin{array}{c}\text { zalecany zabieg } \\
3 \text { szt./roślinę } \\
\text { recommended } \\
\text { treatment } \\
3 \mathrm{pcs} / \text { plant }\end{array}$ & \\
\hline
\end{tabular}


Tabela 5. Wyznaczone terminy zabiegu przeciw występowaniu mączniaka prawdziwego zbóż i traw w latach 2005-2013 w miejscowości Winna Góra

Table 5. The determined dates of chemical treatments against powdery mildew in years 2005-2013 in Winna Góra

\begin{tabular}{|c|c|c|c|}
\hline $\begin{array}{l}\text { Rok } \\
\text { Year }\end{array}$ & $\begin{array}{l}\text { Faza rozwojowa pszenicy ozimej } \\
\text { Winter wheat development stage }\end{array}$ & $\begin{array}{l}\text { Termin zabiegu } \\
\text { Time of treatment }\end{array}$ & $\begin{array}{l}\text { Uwagi } \\
\text { Notes }\end{array}$ \\
\hline 2005 & strzelanie w źdźbło - shooting & 9.05 & $\begin{array}{l}\text { został osiagnięty próg ekonomicznej szkodliwości } \\
\text { threshold of economical harmfulness was achieved }\end{array}$ \\
\hline 2006 & strzelanie w źdźbło - shooting & 15.05 & $\begin{array}{l}\text { został osiągnięty próg ekonomicznej szkodliwości } \\
\text { threshold of economical harmfulness was achieved }\end{array}$ \\
\hline 2007 & $\begin{array}{l}\text { grubienie pochwy liściowej } \\
\text { early boot stage }\end{array}$ & 14.05 & $\begin{array}{l}\text { został osiągnięty próg ekonomicznej szkodliwości } \\
\text { threshold of economical harmfulness was achieved }\end{array}$ \\
\hline 2008 & strzelanie w źdźbło - shooting & 13.05 & $\begin{array}{l}\text { został osiągnięty próg ekonomicznej szkodliwości } \\
\text { threshold of economical harmfulness was achieved }\end{array}$ \\
\hline 2009 & $\begin{array}{l}\text { grubienie pochwy liściowej } \\
\text { early boot stage }\end{array}$ & - & $\begin{array}{l}20.05 \text { małe nasilenie objawów choroby, } \\
\text { nie zalecano zabiegu } \\
20.05 \text { low disease incidence, } \\
\text { treatment was not recommended }\end{array}$ \\
\hline 2010 & strzelanie w źdźbło - shooting & 14.05 & $\begin{array}{l}\text { został osiągnięty próg ekonomicznej szkodliwości } \\
\text { threshold of economical harmfulness was achieved }\end{array}$ \\
\hline 2011 & strzelanie w źdźbło - shooting & - & $\begin{array}{l}26.05 \text { małe nasilenie objawów choroby, } \\
\text { nie zalecano zabiegu } \\
26.05 \text { low disease incidence, treatment was not } \\
\text { recommended }\end{array}$ \\
\hline 2012 & strzelanie w źdźbło - shooting & 21.05 & $\begin{array}{l}\text { został osiągnięty próg ekonomicznej szkodliwości } \\
\text { threshold of economical harmfulness was achieved }\end{array}$ \\
\hline 2013 & $\begin{array}{l}\text { grubienie pochwy liściowej } \\
\text { early boot stage }\end{array}$ & 24.05 & $\begin{array}{l}\text { został osiągnięty próg ekonomicznej szkodliwości } \\
\text { threshold of economical harmfulness was achieved }\end{array}$ \\
\hline
\end{tabular}

Tabela 6. Wyznaczone terminy zabiegu przeciw słodyszkowi rzepakowemu w latach 2006-2013 w miejscowości Winna Góra Table 6. The determined dates of chemical treatments against blossom beetle in years 2006-2013 in Winna Góra

\begin{tabular}{|c|c|c|c|}
\hline $\begin{array}{l}\text { Rok } \\
\text { Year }\end{array}$ & $\begin{array}{l}\text { Faza rozwojowa rzepaku ozimego } \\
\text { Winter rape development stage }\end{array}$ & $\begin{array}{l}\text { Termin zabiegu } \\
\text { Time of treatment }\end{array}$ & $\begin{array}{l}\text { Uwagi } \\
\text { Notes }\end{array}$ \\
\hline 2006 & $\begin{array}{l}\text { rozwój pąków kwiatowych } \\
\text { inflorescence emergence }\end{array}$ & 4.05 & $\begin{array}{l}\text { został osiągnięty próg ekonomicznej szkodliwości } \\
\text { threshold of economical harmfulness was achieved }\end{array}$ \\
\hline 2007 & kwitnienie - flowering & 16.04 & $\begin{array}{l}\text { został osiaggnięty próg ekonomicznej szkodliwości } \\
\text { threshold of economical harmfulness was achieved }\end{array}$ \\
\hline 2008 & $\begin{array}{l}\text { rozwój pąków kwiatowych } \\
\text { inflorescence emergence }\end{array}$ & 16.04 & $\begin{array}{l}\text { został osiągnięty próg ekonomicznej szkodliwości } \\
\text { threshold of economical harmfulness was achieved }\end{array}$ \\
\hline 2009 & $\begin{array}{l}\text { rozwój pąków kwiatowych } \\
\text { inflorescence emergence }\end{array}$ & 15.04 & $\begin{array}{l}\text { został osiągnięty próg ekonomicznej szkodliwości } \\
\text { threshold of economical harmfulness was achieved }\end{array}$ \\
\hline 2010 & $\begin{array}{l}\text { rozwój pąków kwiatowych } \\
\text { inflorescence emergence }\end{array}$ & 22.04 & $\begin{array}{l}\text { został osiągnięty próg ekonomicznej szkodliwości } \\
\text { threshold of economical harmfulness was achieved }\end{array}$ \\
\hline 2011 & $\begin{array}{l}\text { rozwój pąków kwiatowych } \\
\text { inflorescence emergence }\end{array}$ & 28.04 & $\begin{array}{l}\text { został osiągnięty próg ekonomicznej szkodliwości } \\
\text { threshold of economical harmfulness was achieved }\end{array}$ \\
\hline 2012 & $\begin{array}{l}\text { rozwój pąków kwiatowych } \\
\text { inflorescence emergence }\end{array}$ & 23.04 & $\begin{array}{l}\text { został osiaggnięty próg ekonomicznej szkodliwości } \\
\text { threshold of economical harmfulness was achieved }\end{array}$ \\
\hline 2013 & $\begin{array}{l}\text { rozwój pąków kwiatowych } \\
\text { inflorescence emergence }\end{array}$ & 29.04 & $\begin{array}{l}\text { został osiągnięty próg ekonomicznej szkodliwości } \\
\text { threshold of economical harmfulness was achieved }\end{array}$ \\
\hline
\end{tabular}

Obserwacje nad pojawianiem się na rzepaku ozimym słodyszka rzepakowego $\mathrm{w}$ latach 2012 i 2013 prowadzono w miejscowościach: Winna Góra, Kościelna Wieś, Baborówko, Sośnicowice, Torun i Białystok.

W roku 2012 punktem obserwacyjnym, w którym chrząszcze na rzepaku obserwowano najwcześniej było Baborówko (23.03), już 16 kwietnia stwierdzono średnio 3 szt. na 1 roślinie, co było sygnałem do wyznaczenia terminu zabiegu, który został wykonany 20 kwietnia.
W marcu stwierdzono także nalot tego szkodnika w Winnej Górze (26.03) i Sośnicowicach (27.03). Natomiast w pozostałych miejscowościach w kwietniu w Kościelnej Wsi (10.04) i w Białymstoku (dopiero 27.04). Termin zwalczania słodyszka rzepakowego (poza Baborówkiem) wyznaczono najwcześniej w dniach 20-23 kwietnia w miejscowościach: Winna Góra, Kościelna Wieś, Sośnicowice, a najpóźniej w dniu 27 kwietnia w Białymstoku (tab. 3). 
W roku 2013 punktami obserwacyjnymi, w których chrząszcze słodyszka rzepakowego na rzepaku obserwowano najwcześniej były: Baborówko (15.04), Sośnicowice i Białystok (16.04) oraz Kościelna Wieś (19.04). Nie stwierdzono początku nalotu chrząszczy w Winnej Górze i Toruniu. We wszystkich wymienionych miejscowościach liczebność szkodnika osiągnęła lub przekroczyła wartość progu ekonomicznej szkodliwości. Termin zwalczania wyznaczono najwcześniej w Sośnicowicach (24.04), a następnie kolejno w miejscowościach: Baborówko (26.04), Winna Góra (29.04), Kościelna Wieś (4.05), Białystok (6.05) i Toruń (8.05) (tab. 4).

$\mathrm{Na}$ podstawie przedstawionych wyników monitorowania występowania mączniaka prawdziwego zbóż i traw na pszenicy ozimej oraz słodyszka rzepakowego na rzepaku ozimym można stwierdzić, że wyznaczane terminy zwalczania tych agrofagów były różne $\mathrm{z}$ uwagi na inny mikroklimat występujący w punktach obserwacyjnych. Potwierdza to pogląd, że monitorowanie agrofagów w celu zaobserwowania pojawiania się objawów chorobowych i oceny stopnia ich nasilenia lub występowania szkodnika w jego określonych stadiach rozwojowych, w których należy wykonać zabieg ochrony chemicznej najlepiej spełnia swoją rolę wówczas, gdy jest prowadzone na konkretnej plantacji.

Mając na uwadze zmieniające się corocznie warunki meteorologiczne, wyniki monitorowania przedstawiono na przykładzie występowania mączniaka prawdziwego zbóż i traw na pszenicy ozimej w latach 2005-2013 oraz słodyszka rzepakowego na rzepaku ozimym w latach 20062013 w miejscowości Winna Góra (tab. 5, 6).

Wykonanie zabiegu przeciw występowaniu mączniaka prawdziwego zbóż i traw na pszenicy ozimej w Winnej Górze (tab. 5) na przestrzeni 9 lat tylko w dwóch latach (2009 i 2011) nie miało ekonomicznego uzasadnienia $\mathrm{z}$ uwagi na małe nasilenie objawów tej choroby. W latach 2007 i 2010 zabieg wykonano w jednakowym terminie, tj. 14 maja, chociaż pszenica ozima była w różnych fazach rozwojowych. W pozostałych latach terminy zabiegu były różne, od 9 maja w roku 2005 do 24 maja w 2013 roku.

Wykonanie zabiegu przeciw słodyszkowi rzepakowemu na rzepaku ozimym w Winnej Górze (tab. 6) na przestrzeni 8 lat, w dwóch latach (2007 i 2008), wyznaczono $\mathrm{w}$ jednakowym terminie, tj. 16 maja, ale w różnych fazach rozwojowych rzepaku. W pozostałych latach ter- miny zabiegu były różne, od 15 kwietnia w roku 2009 do 4 maja w 2005 roku.

Wyniki monitorowania przedstawione w tabelach 5 . i 6. potwierdzają konieczność corocznego monitorowania agrofagów $\mathrm{z}$ uwagi na każdego roku różny przebieg warunków pogodowych, co powoduje zróżnicowane występowanie agrofagów i tempo ich rozwoju oraz w konsekwencji konieczność wykonania zabiegu przypadającą także $\mathrm{w}$ innym terminie.

\section{Wnioski / Conclusions}

1. Monitorowanie agrofagów w celu zaobserwowania pojawiania się objawów chorobowych i oceny stopnia ich nasilenia lub liczebności szkodników w określonych stadiach ich rozwoju najlepiej spełnia swoją rolę, jeśli jest prowadzone na konkretnej plantacji i corocznie, z powodu różnego w latach przebiegu warunków pogodowych.

2. Wykorzystanie wyników badań przyczyni się do zminimalizowania ryzyka wystąpienia szkód spowodowanych przez agrofagi i wyeliminowania nadmiernego, niepotrzebnego zużycia chemikaliów na plantacjach położonych w najbliższym sąsiedztwie punktów obserwacyjnych serwisu informacyjnego ,Sygnalizacja Agrofagów".

3. Producenci lub doradcy, którzy mają plantacje zlokalizowane w innych rejonach kraju niż wymienione punkty obserwacyjne mogą skorzystać z części edukacyjnej serwisu informacyjnego, w której znajdą podstawowe informacje o morfologii i biologii wybranych agrofagów oraz metodach prowadzenia obserwacji polowych i progach ekonomicznej szkodliwości. Informacje te zamieszczone są pod hasłami „Opis i szkodliwość” oraz ,Zwalczanie” i są pomocne w samodzielnym kontrolowaniu plantacji, wyznaczaniu właściwego terminu zabiegu i świadomym podejmowaniu decyzji o wykonaniu zabiegu ochrony roślin.

4. Korzystając $\mathrm{z}$ serwisu informacyjnego producenci uzyskują dostęp do informacji o występowaniu innych agrofagów nieobjętych sygnalizacją, które w tym serwisie zamieszczane są pod hasłem „Aktualności”.

\section{Literatura / References}

Aneksy do Instrukcji dla służby ochrony roślin z zakresu prognoz, sygnalizacji i rejestracji - do części II, tom I i II (1993) „Metody sygnalizacji i prognozowania pojawu chorób i szkodników roślin oraz do części III (1976) „Rejestracja ogólna i szczegółowa chorób i szkodników roślin uprawnych”. 1998. Wyd. I. Inst. Ochr. Roślin, Poznań, 47 ss.

Instrukcja dla służby ochrony roślin z zakresu prognoz, sygnalizacji i rejestracji. Część I Ogólna. 1982. Wyd. V. Inst. Ochr. Roślin, Poznań, 165 ss.

Instrukcja dla służby ochrony roślin z zakresu prognoz, sygnalizacji i rejestracji. Część II t. I i II Metody sygnalizacji i prognozowania pojawu chorób i szkodników roślin. 1993. Wyd. IV. Inst. Ochr. Roślin, Poznań, t. I, 200 ss., t. II, 200 ss.

Instrukcja dla służby ochrony roślin z zakresu prognoz, sygnalizacji i rejestracji. Część III Rejestracja ogólna i szczegółowa chorób i szkodników roślin uprawnych. 1976. Wyd. IV. Inst. Ochr. Roślin, Poznań, 162 ss.

Walczak F. (red.). 2007. Poradnik sygnalizatora ochrony zbóż. Inst. Ochr. Roślin, Poznań, 111 ss. ISBN 978-83-89867-90-2.

Walczak F. (red.). 2008. Poradnik sygnalizatora ochrony rzepaku. Inst. Ochr. Roślin - PIB, Poznań, 153 ss. ISBN 978-83-89867-90-2.

Walczak F., Bandyk A., Jakubowska M., Roik K., Tratwal A., Wielkopolan B., Złotkowski J. 2013. Stan fitosanitarny roślin uprawnych w Polsce w roku 2012 i spodziewane wystąpienie agrofagów w 2013. Inst. Ochr. Roślin - PIB, Poznań, 120 ss. ISSN 1898-7419. 